\title{
The Petrography, Mineralography and Microprobe Analysis on New Exploratory Excavation Phase in Sarcheshmeh Copper Mine Pit and Comparing Them with Existing Data from the Other Area in South West Sarcheshmeh
}

\author{
Mehdi Abdollahy Riseh*, Mansur Vosooghi Abedini, Mohammad Hashem Emami, \\ Seyed Jamal Sheikh Zakariaei
}

Department of Geology, Science and Research Branch, Islamic Azad University, Tehran, Iran

Email: ^abdollahy_m@nicico.com

How to cite this paper: Riseh, M.A., Abedini, M.V., Emami, M.H. and Zakariaei, S.J.S. (2017) The Petrography, Mineralography and Microprobe Analysis on New Exploratory Excavation Phase in Sarcheshmeh Copper Mine Pit and Comparing Them with Existing Data from the Other Area in South West Sarcheshmeh. Open Journal of Geology, 7, 162-181.

https://doi.org/10.4236/ojg.2017.72011

Received: December 28, 2016

Accepted: February 21, 2017

Published: February 24, 2017

Copyright (c) 2017 by authors and Scientific Research Publishing Inc. This work is licensed under the Creative Commons Attribution International License (CC BY 4.0).

http://creativecommons.org/licenses/by/4.0/

\section{(c) (i) Open Access}

\begin{abstract}
Kerman region where Sarcheshmeh zone is located includes the end part of Uremia-Dokhtar Zone. Extrusive igneous group in Sarcheshmeh is as follows: 1) andesite and 2) rhyodacite. The group of intrusive igneous rocks includes 1) porphyry granite, 2) porphyry granodiorite, and 3) porphyry diorite. Nochoon mine is located at $4 \mathrm{~km}$ of southwest of Sarcheshmeh copper mine and it comprises of a group of extrusive igneous rocks as follows: 1) andesite, and 2) dacite. Based on results of microprobe analysis, pyroxene mineral's composition in these rocks of diopside and augite indicates amphiboles of composite zone of magnesium hosting type and existing plagioclases in regional rock for labradorite and bitonit composition. The most common compounds are chlorite with formula among antigorite and amosite. Comparison of magnetite mineralization in Sarcheshmeh and Nochoon indicates vein mineralization in Nochoon and disseminated granulation in Sarcheshmeh and particularly concerning to chalcopyrite, Nochoon includes more veins than Sarcheshmeh.
\end{abstract}

\section{Keywords}

Petrography, Microprobe Chemical Analysis, Sarcheshmeh Mine, Kerman

\section{Introduction}

Kerman region where Sarcheshmeh zone is located includes the end part of Ure- 
mia-Dokhtar zone and generally petrologic units in this system (i.e. one of the most marvelous geological structures in Kerman region) comprise of clastic igneous and volcano clastic rocks from Eocene epoch and also in many regions, subvolcanic rocks (semi-deep plutonic) at aged oligomiocene and volcanic rocks of quaternary sediments are accompanied with these formations. In this group, rocks have mainly volcanic origin. The older rocks, which have created these formations, lack facies. Plutonic and semi-deep rocks as well as dikes have crossed this zone in many points. Due to the lack of distinct fossil in rock units in major part of this system, age of this system has been approximated by petrologic relation and comparison with similar formations in other zones. Nonetheless, age of these sedimentary-volcanic formations has been considered from lower to upper Eocene and studied zone (Nochoon) is also included as a part of this system. Sarcheshmeh mine is located $160 \mathrm{~km}$ distance from southwest of Kerman city, $50 \mathrm{~km}$ from south of Rafsanjan city, and $36 \mathrm{~km}$ from Pariz town. This mine is situated on geographical latitude $\left(29^{\circ} 58^{\prime} \mathrm{N}\right)$ and longitude $\left(55^{\circ} 53^{\prime} \mathrm{E}\right)$. Geology of zone comprises of Eocene volcanic-sedimentary group that is one of the most interesting geological structures in Kerman region. This system has northwest-southeast trend with length $500 \mathrm{~km}$ and at least $15 \mathrm{~km}$ diameter. The major part of this system is composed of different rocks with volcanic origin. The older rocks that have created basis for these structures have no facies in Sarcheshmeh zone. Plutonic and semi-deep rocks as well as dikes have crossed this group in many points. Due to absence of fossil in Sarcheshmeh zone, age of this system has been estimated by petrologic relations and comparison with similar structures in other zones. Based on this technique, age of this system has been considered as upper Eocene including transition from middle Eocene to upper Eocene. Sedimentary deposits from third and fourth geologic periods have been spread on Sarcheshmeh zone as well. The studied rocks in this zone include extrusive and intrusive igneous rocks. The extrusive igneous group comprises of: 1) andesite and 2) rhyodacite. The group of intrusive igneous rocks includes: 1) monzogranite, 2) granodiorite, and 3) diorite and semi-deep igneous rocks consist of: 1) porphyry granite, 2) porphyry granodiorite, and 3) porphyry diorite.

With area of $9.1 \mathrm{~km}^{2}$, Nochoon mine is located on the southeastern piedmont of Mamzar Mount $4 \mathrm{~km}$ distance from southwest of Sarcheshmeh cooper mine and $10 \mathrm{~km}$ from northeast of Pariz zone with geographic situation (eastern longitude: $55^{\circ} 47^{\prime} 06^{\prime \prime}-55^{\circ} 49^{\prime} 45^{\prime \prime}$ ) and (northern latitude: $\left.29^{\circ} 55^{\prime} 28^{\prime \prime}-29^{\circ} 57^{\prime} 05^{\prime \prime}\right)$ and it is about $150 \mathrm{~km}$ distant from the center of province and facies rock units in Nochoon zone mainly include volcanic and pyroclastic rocks of Eocene, deep plutonic masses, and Oligocene semi-deep apophyses, intermediate dikes, numbers of silica vein and alluvial sediments from Quaternary and present period. Based on prepared geologic map, the plutonic and subvolcanic units include mainly outcrop at central and southern regions and volcanic-pyroclastic units widely in other parts of this zone. Separated rock units are described on geologic map (1:1000) within Nochoon zone based on age order from older to younger in the following (Figure 1). The studied rocks in Nochoon zone are classified in group of extru- 
sive igneous rocks including 1) andesite and 2) dacite. Nochoon mine with over $9.1 \mathrm{~km}^{2}$ of area is located on piedmont of Mamzar Mount and $4 \mathrm{~km}$ distance from southwest of Sarcheshmeh copper mine and $10 \mathrm{~km}$ from northeast of Pariz in geographic situation (eastern longitude: $55^{\circ} 47^{\prime} 06^{\prime \prime}-55^{\circ} 49^{\prime} 45^{\prime \prime}$ ) and (northern latitude: $29^{\circ} 55^{\prime} 28^{\prime \prime}-29^{\circ} 57^{\prime} 05^{\prime \prime}$ ) and it is about $150 \mathrm{~km}$ distant from the center of province and facies rock units in Nochoon zone mainly include volcanic and pyroclastic rocks of Eocene, deep plutonic masses, and Oligocene semi-deep apophyses, intermediate dikes, numbers of silica vein and alluvial sediments from Quaternary and present period. According to prepared geologic map, plutonic and subvolcanic units mainly include outcrop at central and southern regions and volcanic-pyroclastic unit locating widely in other parts of this zone. The studied rocks in Nochoon zone are classified in group of extrusive igneous rocks that comprise of 1) andesite and 2) dacite (Figure 2(a)). With respect to new exploratory excavations (fourth phase of exploratory excavation started since 2011) and more perfect samplings, especially in unexplored underground parts and achieving depth data (excavation at depth $750 \mathrm{~m}$ ) and related information about margins of Sarcheshmeh mine, necessity for analysis of petrographic and mineralography properties becomes more obvious in masses of Sarcheshmeh zone. It should be noted that this study is intended to analyze petrography, petro fabric, mineralography, magmatic developments and processes, determination of temperature-barometry in igneous rock units relating to exploratory excavation soundings in new phase on Sarcheshmeh mine (Figure 2) and finally results of studies on Sarcheshmeh and Nochoon mines will be compared.

\section{Methodology}

Analysis on petrographic data may put very valuable information about petrographic nature and magmatic developments at our disposal. Accordingly, very accurate samples were extracted from various rocks in the studied zones (Nochoon and Sarcheshmeh). During sampling, 350 rock samples were extracted including various types of intrusive and extrusive igneous rocks (Figure 1). Among this number, 120 samples were selected with respect to lack of iteration and given strength and thin section. In order to identify composition of constituent minerals in these rocks, 14 samples of regional rocks were selected including basalt, basaltic andesite, andesite, and a pyroclastic sample and minerals of pyroxene,

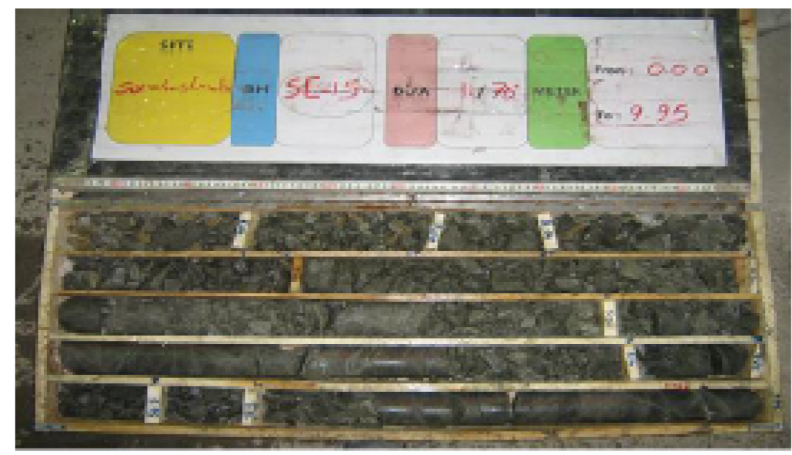

Figure 1. A view from exploratory excavation care boxes at fourth phase. 
(a)

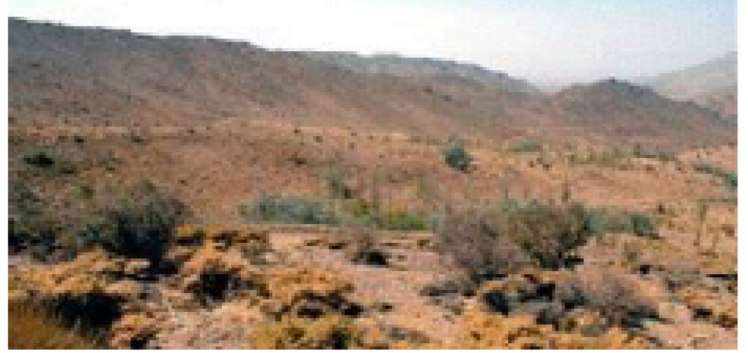

(b)

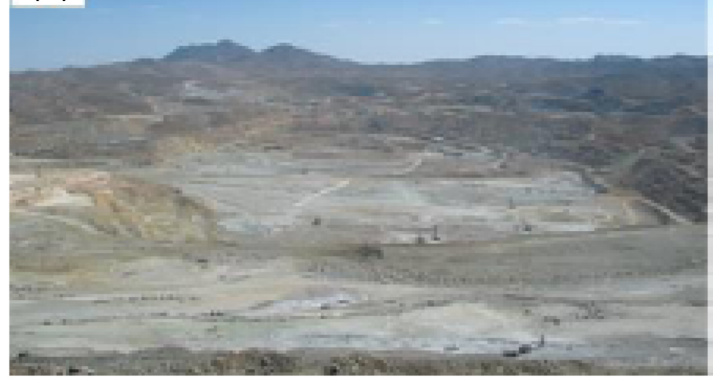

Figure 2. (a) A view from topography of Nochoon molybdenum-copper mine; (b) A view from topography of Sarcheshmeh copper mine.

amphibole, plagioclase, epidote, chlorite and two samples of subsidiary minerals such as rutile and apatite were examined by electron-probe micro analysis. Electron-Probe Micro Analysis (EPMA) was done on 120 points at Iranian researcher centers for processing of minerals by camera (model: SX-100). Composition of constituent minerals on regional rocks was determined according to the given results from Electron-Probe Micro Analysis (EPMA) by diagrams for determination of mineral compositions presented by different researchers.

\section{Discussion and Results}

\subsection{Petrography of Regional Rocks}

After conducting study on thin section, rocks in Sarcheshmeh zone were divided into three groups i.e. extrusive, intrusive, and semi-deep igneous rocks. External igneous group includes: 1) andesite, and 2) rhyodacite. Group of intrusive igneous rocks comprises of: 1) monzogranite, 2) granodiorite, and 3) diorite and group of semi-deep igneous rocks consists of: 1) porphyry granodiorite, 2) porphyry diorite, and 3) porphyry granite. The studied rocks in Nochoon zone are classified in group of extrusive igneous rocks including: 1) andesite and 2) dacite. We conduct petrographic analysis on extrusive igneous rocks in Sarcheshmeh and Nochoon zones in this study.

\subsection{Petrography of Extrusive Igneous Rocks in Sarcheshmeh Zone}

Andesite rocks in Sarcheshmeh zone include porphyry texture and microlithic paste with phenocrysts of plagioclase, biotite, amphibole, and resulting pastes and minerals from alteration such as clay minerals, opaque minerals, chlorite, and calcite. Plagioclases are seen with form and amorphous and in different sizes and with albite-pericline macle and albite-Carlsbad in oscillatory zoning in body of rock. Plagioclases include three geneses in these rocks: First genesis plagioclases (Pl-1) that lack imbalanced textures. Second-genesis plagioclases ( $\mathrm{Pl}-2)$ comprise of oscillatory zoning texture. Third-genesis plagioclases (Pl-3-C-R) consist of imbalance texture of screening type within distance among center to near to margin. Wet sodic plagioclase has formed at external margin of overgrowth (Figure 
3(a) \& Figure 3(b)).

Biotite is seen in scaly form to amorphous with mean size of $860 \mu \mathrm{m}$ and in several colors of dark brown to pale brown within body of rock. Some evidences of solubility may be found at the margin of these biotite rocks. One can refer to apatite as one of the existing evolutions in these minerals. Opaque minerals and calcite are implied as alteration products in these biotite rocks. Amphibole is visible with form and amorphous and with mean size $(420 \mu \mathrm{m})$ inside the body of rock and they have been totally replaced by calcite and they can be only distinguished through crystalline forms. Most of plagioclase pastes have been replaced by sericite and calcite. One can refer to clay minerals, opaque minerals, chlorite, and calcite as resulting mineral from alteration.

Rhyodacite with porphyritic texture and microlithic to unclear paste comprises of constituent minerals such as quartz, plagioclase, biotite, subsidiary minerals, altered minerals and paste. Quartz is visible as amorphous (with circular appearance) with soluble and bay-shaped margins and evolutions on background at mean size $380 \mu \mathrm{m}$ inside the body of rock. Plagioclase is seen with form to amorphous along with macled albite-pericline, albite-Carlsbad and in some cases with mono crystalline and associative zoning inside body of rock. Some plagioclases have been altered at center and margin and some others totally by quartz and sericite. One can refer to sericite (Ser) at high level and chlorite (Chl), and calcite (Cal) at smaller quantity as alteration products in these plagioclases. Biotite has been excessively altered in scaly form to amorphous in some cases. One can refer to opaque minerals (Op-2) and chlorite as products of alteration of these biotite minerals. This paste has formed of quartz and feldspar. Feldspars are replaced by sericite and clay minerals. One can imply semi-formed to amorphous opaque minerals of these subsidiary minerals which are seen independently as (Op-1) and associative form along with chlorites and medium crystalline quartz (Op-3). Chlorite, sericite, quartz, and calcite may be called as resulting minerals from alteration (Figure 4(a) \& Figure 4(b)).

Rhyolite includes porphyritic texture and microgranular paste to unclear texture. The constituent minerals in this rock include quartz, alkaline feldspar, plagioclase, biotite, subsidiary minerals and paste. Quartz is visible as amorphous
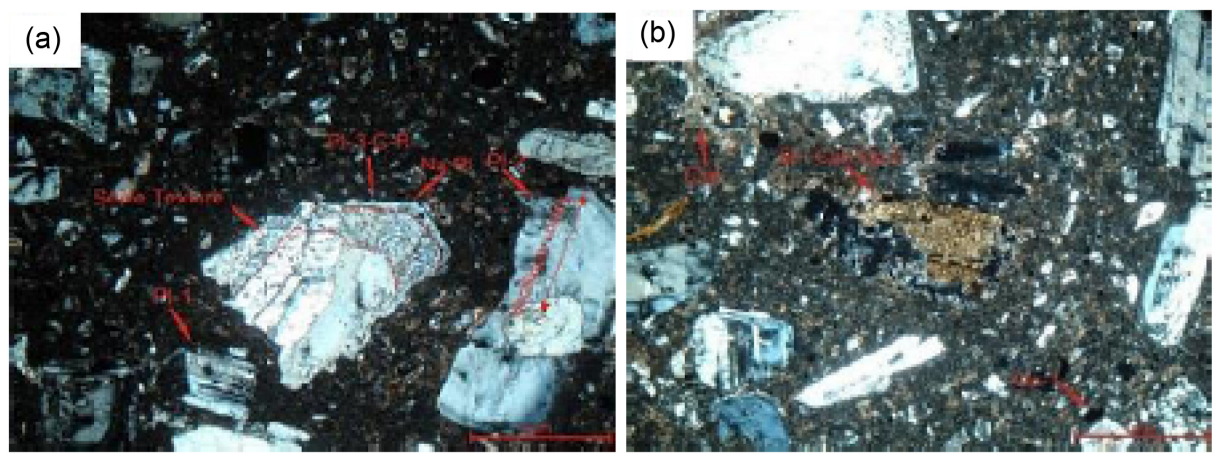

Figure 3. (a) A view from different plagioclase geneses in andesite rocks of zone; (b) A view from altered biotite into calcite and opaque minerals. 

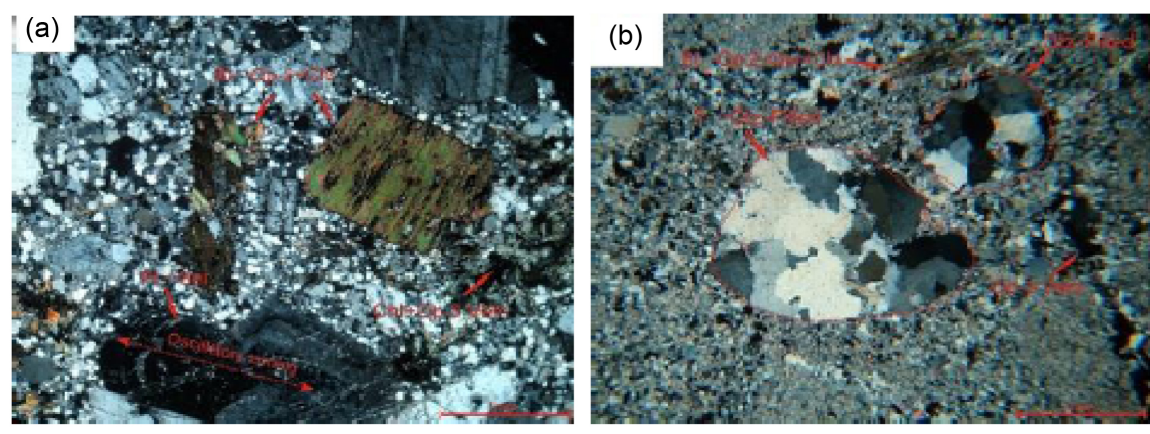

Figure 4. (a) A view from plagioclase phenocryst with oscillatory zoning in rhyodacite rocks in the zone; (b) A view from plagioclase phenocryst replaced with quartz (red dots) in riolites (XPL).

with soluble and bayside margins and some evolutions on background. Alkaline feldspars are found of orthose type, with form to semi-amorphous, and evolutions of plagioclases. On most of occasions, plagioclases are fully replaced by sericite and in some cases totally by quartz. Biotite has been replaced excessively in scaly form to amorphous by chlorite, sericite, and opaque minerals (Op-2). Also paste has formed of quartz and fine-crystal feldspars. One can also refer to opaque minerals and sericite and striated and associative quartzes as subsidiary minerals. Resulting minerals from alteration are clay minerals, chlorite, sericite, and calcite.

\subsection{Petrography of Extrusive Igneous Rocks in Nochoon Zone}

Andesite with porphyritic texture and microlithic paste consist of constituent minerals of plagioclase, amphibole, and subsidiary minerals and paste. Plagioclase is visible with formed to amorphous and in some cases with albite-Carlsbad macle and albite-pericline. These plagioclases have been replaced by sericite, chlorite, and calcite in some cases (Figure 5(a)). Amphibole is seen in semiformed to amorphous with sizes ranged from $150 \mu \mathrm{m}$ to $260 \mu \mathrm{m}$ and with low frequency. These minerals have been extremely altered by chlorites and opaque minerals. Such replacement is to the extent that these minerals may not be recognized by external shape and facies. One can refer to subsidiary minerals such as independent and striated formed to amorphous opaque minerals together with medium-size crystalline quartz and fine-crystalline scaly biotite. This paste is composed of extremely altered fine plagioclase crystals to sericite and replaced by silica and substituted fine-crystalline to scaly biotite minerals (metasomatic). One can refer to opaque minerals, sericite, calcite, biotite, and chlorite as the resultant minerals from alteration. Dacite minerals in Nochoon zone with porphyritic texture and microgranular paste include constituent plagioclase minerals, biotite, paste, and subsidiary minerals. Plagioclase is seen in formed to amorphous and with macled albite-Carlsbad and albite-pericline inside body of rock. With respect to optic properties, these plagioclases are of albite type to oligoclase. Biotite minerals are visible in semi-formed to amorphous with low frequency. These minerals have been extremely replaced by calcite, chlorite, and opaque 

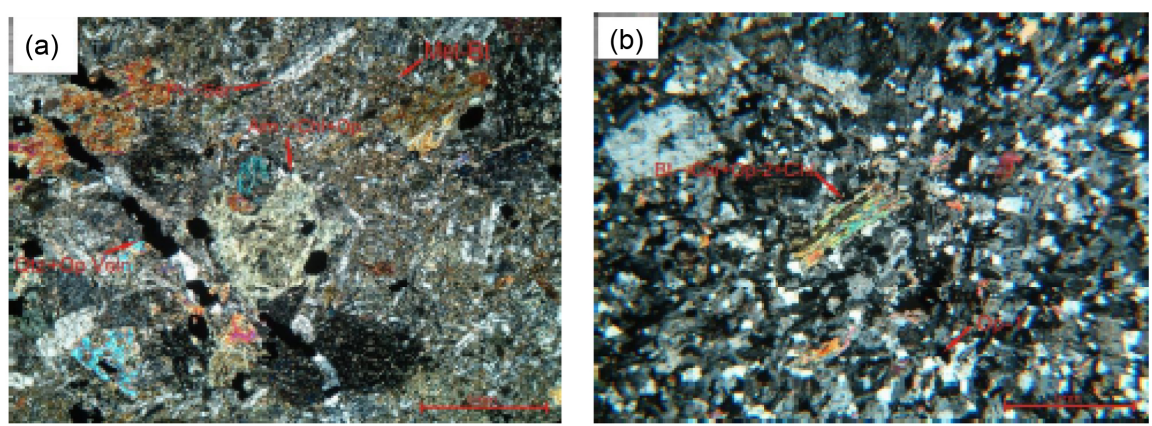

Figure 5. (a) A view from excessively altered plagioclase into sericite; altered amphiboles. (b) A view from excessively altered biotite into calcite (XPL).

minerals (Figure 5(b)). This paste is composed of plagioclase and fine crystalline quartzes and it has been slightly replaced by sericite. One can refer to formed to amorphous mono-crystalline opaque minerals as subsidiary minerals, which are observed disseminated form inside it. The resulting minerals from alteration are also clay minerals, chlorite, sericite, and calcite.

\subsection{Mineralography of Rocks in Sarcheshmeh Zone}

Study on finished sections shows in Sarcheshmeh zone that the original ores in studied sections include pyrite, chalcopyrite, and magnetite. The minor ores also comprise of chalcocite, covellite, bornite, and hematite. Magnetite as a common and abundant mineral in most of samples has formed dispersedly as granular in paste of primary igneous rock and it has been the first mineralization phase in Sarcheshmeh zone and its texture is composed of disseminated granular type. Sometimes this mineral has been replaced in background as co-existing growth and along with disseminated crystals of pyrite (Figure 6(a)). Magnetite mineral has been impacted by subsequent hydrothermal phases in some of studied samples where this impact is visible in leached magnetite crystals as well as formation of magnetite veins along with silicification phenomenon. Pyrite is the major and most frequent metallic mineral in these sections. Pyrite mineralization is done in most of samples in veined form and crossing of veins forms structures e.g. stock and rack. At least four generations of pyrite mineral were identified in finished sections of Sarcheshmeh zone:

1) Pyrite crystals with disseminated texture: Disseminated mineralization of pyrite in Sarcheshmeh is done as formation of crystals without facies to crystals with facies (euhedral) and with margins created by chalcopyrite inside the enclosed crystals that indicate pyrite mineralization occurred before chalcopyrite.

2) Mineralization of veined first-generation pyrite: The first generation pyrite mineralization is related to very thin veins (with diameter about $1 \mathrm{~mm}$ ). These veins are not continuous in parts of background and discontinuity in mineralization has been filled through non-metallic replacement (probably silica). Firstgeneration veins have been crossed by second- and third-generation pyrite veins.

3) Second-generation veined pyrite mineralization: Second-generation veins with pyrite mineralization have crossed first-generation veins and they are crossed 

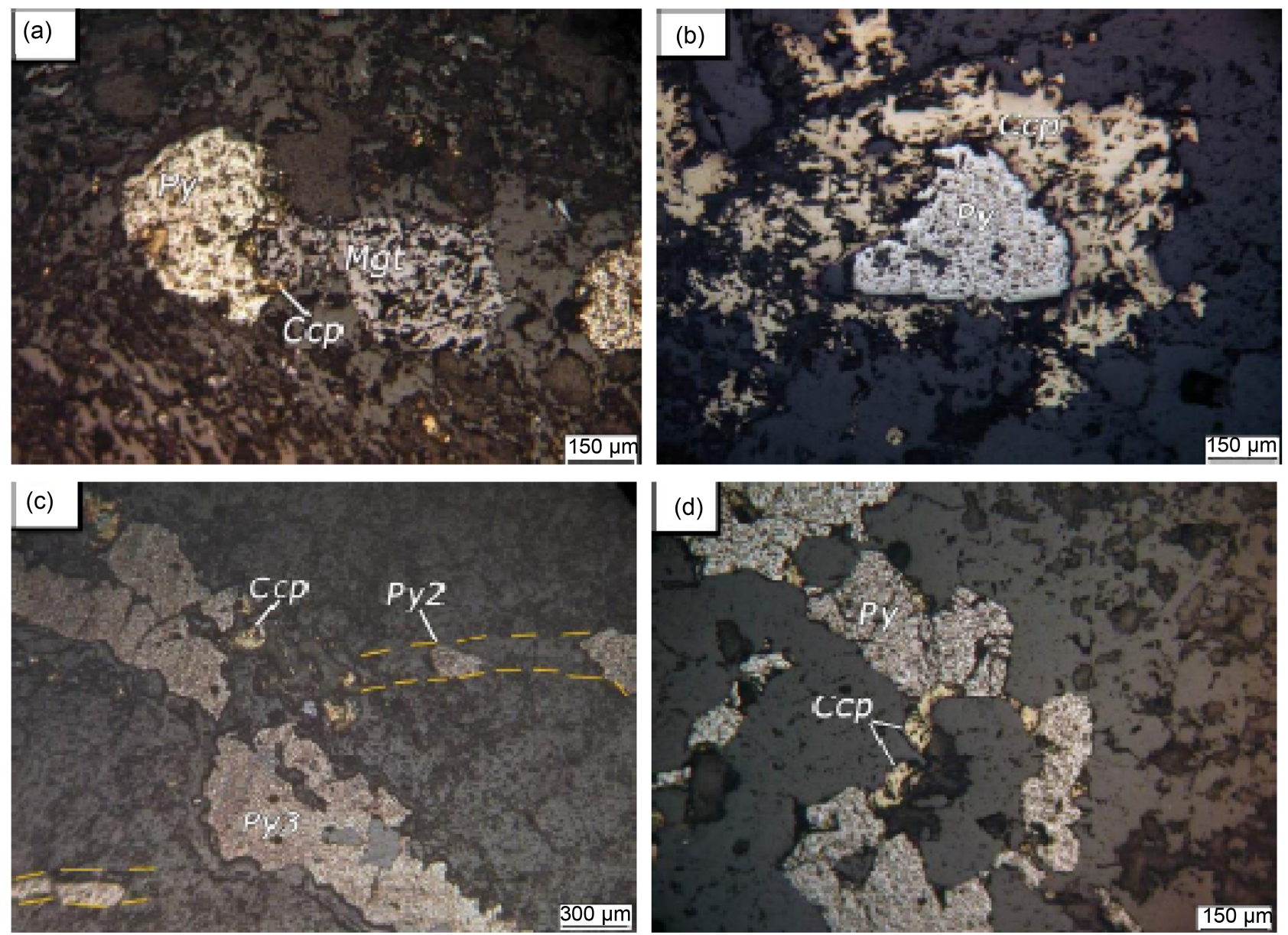

Figure 6. (a) Coexisting growth of magnetite and pyrite that have been crossed by chalcopyrite vein; (b) Pyrite inclusion by chalcopyrite: It shows the solved levels of pyrite that has been circumscribed by chalcopyrite after formation of pyrite; (c) Breccia pyrite in which the interstitial space in second-generation vein veins (Py2) have been crossed by third-generation pyrite-chalcopyrite vein (Py3); (d) Vein mineralization of pyrite and chalcopyrite in rock background.

by third-generation veins. These veins are a bit thicker than first-generation veins. These veins have formed sometimes along with chalcopyrite mineralization as well as non-metallic veins (probably silica). Chalcopyrite is visible as coexisting growth with inclusion inside pyrite veins.

4) Third-generation veined pyrite mineralization: The paramount generation of mineralization in Sarcheshmeh is related to these veins in which following to intrusion of hydrothermal solution into rock background, veined mineralization is created as thick veins (up to $5 \mathrm{~mm}$ or greater) of pyrite and chalcopyrite. Formation of pyrite is prior to chalcopyrite in third-generation veined mineralization so that thick pyrite veins are sheared mainly by penetration of subsequent hydrothermal solutions and chalcopyrite with non-metallic veins have filled the space among them (Figure 6(b)). Similarly, chalcopyrite is also visible as inclusions inside pyrite (Figure 6(c)).

Chalcopyrite is seen with color of yellow to green in samples with high frequency. Coexisting growth of two minerals of chalcopyrite and pyrite and pyrite inclusion by chalcopyrite and inversely inclusion of chalcopyrite by pyrite is sign 
of presence of various generations of chalcopyrite mineral. Overall, three generations of chalcopyrite mineralization were identified in sections at Sarcheshmeh zone: 1) Disseminated (granular) mineralization of chalcopyrite: It is visible in form of disseminated crystals without facies. Chalcopyrite crystals and inclusions by pyrite veins are related to this generation of chalcopyrite mineralization. 2) Chalcopyrite veins: These veins have formed as thin to slightly thick veins mainly together with silicic veins. Sometimes, silicic parts inside these veins have been included by chalcopyrite. 3) Chalcopyrite veins together with third-generation pyrite veins: This chalcopyrite generation as thin and thick veins has mainly filled the space between veined pyrite crystals and it is younger than pyrite veins (Figure 6(d)). Mineralization paragenetic sequence of Sarcheshmeh zone is given in Figure 7.

Mineralography of rocks in Nochoon zone: Magnetite and hematite lack high frequency in various sections of Nochoon zone. In these samples, magnetite crystals have formed many associations due to intrusion of hydrothermal solutions and they are sometimes seen in veined form along with hydrothermal solutions. This mineral is also seen in veined form in addition to hematite mineral resulting from magnetite. This sample in which oxidation and tarnishing of sulfide minerals is observed is hematite mineral resulting from oxidation of primary sulfides such as pyrite. Formation of non-metallic (silicic) vein along with hematite vein is another sign of creation of these veins together with hydrothermal solutions that strengthen pyrite origin for hematite mineral. This generation of hematite veins has been crossed by chalcopyrite vein that indicates younger event of chalcopyrite mineralization (Figure 8(a)). We may find by comparing magnetite and hematite mineralization in Nochoon zone that magnetite mineral has been less spread in background rock in Nochoon zone. On the other hand, process of conversion of magnetite to hematite is more frequent in Nochoon than in Sarcheshmeh zone and magnetite has been more impacted by hydrothermal solutions in Nochoon zone. Rather than magnetite origin in Nochoon

\begin{tabular}{|c|cc|}
\hline Ore & $\begin{array}{c}\text { Primary phases } \\
\text { of mineralization }\end{array}$ & $\begin{array}{c}\text { Final phases } \\
\text { of mineralization }\end{array}$ \\
\hline Magnetite & \\
\hline Pyrite & \\
\hline Chalcopyrite & \\
\hline Bornite & \\
\hline Chalcocite & \\
\hline Covellite & \\
\hline
\end{tabular}

Figure 7. Mineralization paragenetic sequence in Sarcheshmeh zone. 

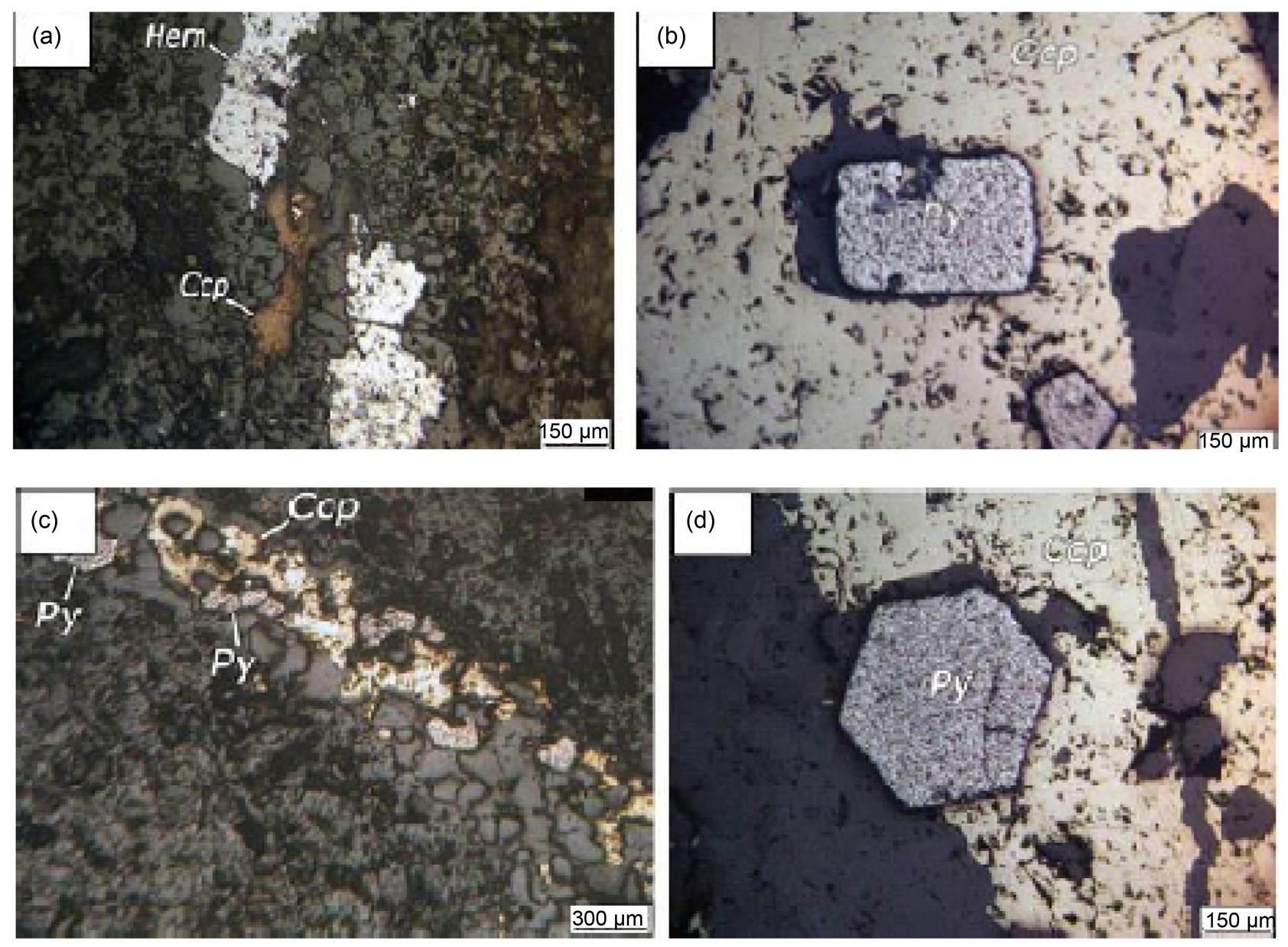

Figure 8. (a) The oxide chalcopyrite vein that has crossed hematite vein together with silica and it is younger than given vein; (b) Growth of second-generation dispersed-grain crystals of pyrite inside chalcopyrite massive mineral created after formation of chalcopyrite; (c) Euhedral pyrite belongs to the last mineralization generation in pyrite and grew inside chalcopyrite; (d) Formation of vein pyrite and chalcopyrite inside the vein.

zone, hematite has also formed due to oxidation of primary sulfides such as pyrite and in veined form.

Chalcopyrite mineral is widely frequent in Nochoon and at least three generation of chalcopyrite mineral was identified in Nochoon zone: 1) Disseminated granular mineralization: Process of mineralization is not too noticeable and this first generation mineralization; 2) Veined chalcopyrite mineralization: This generation of chalcopyrite has formed major part of mineralization that is composed of thin and thick veins of chalcopyrite and discontinuous and short veins. 3) Veined chalcopyrite and pyrite mineralization: In most of sections, this generation of mineralization has crossed first-generation veined chalcopyrite mineralization that is replaced along with pyrite as well as sometimes silicic veins (Figure 8(b)).

Generally, through comparing chalcopyrite mineralization in Sarcheshmeh and Nochoon zones, we concluded that mineralization is wider especially in terms of vein in Nochoon but disseminated chalcopyrite mineralization is more visible in Sarcheshmeh. Similarly, various different generations may be compared in chal- 
copyrite mineralization in these two minerals.

Pyrite is spread widely in Nochoon similar to Sarcheshmeh and it is mainly accompanied to chalcopyrite mineralization. This mineral is totally different from Sarcheshmeh in terms of various paragensis generations two generations of veined mineralization and disseminated granular mineralization have been identified in this mineral so that they have been described as follows: 1) First-generation disseminated pyrite: This generation of pyrite mineralization is visible as crystals with/without facies and in disseminated granular form in rock background. 2) First-generation veined pyrite mineralization: It is seen as veins composed of pyrite and also with small part of chalcopyrite. This generation of mineralization with thicker pyrite veins has been crossed by second-generation veined pyrite mineralization. The second-generation veined pyrite mineralization: The youngest mineralization generation of pyrite belongs to this generation locating in Nochoon that is composed of cubic pyrite crystals totally with facies (euhedral). Presence of pyrite crystals with facies that is enclosed by chalcopyrite is a sign of this phenomenon that chalcopyrite has already existed and these crystals have grown later (Figure $8(c)$ ). There is background of pyrite crystals in some parts in which this margin has been removed following to growth of chalcopyrite at the margin and it is sign of formation of chalcopyrite after forming those pyrite crystals. Therefore, there are two disseminated granular pyrite mineralization generations in Nochoon (Figure $8(\mathrm{~d})$ ). Thus, it is characterized by comparison of pyrite and chalcopyrite mineralization in Nochoon with Sarcheshmeh that mineralization in these two minerals is different from each other in terms of various paragensis and generations. Mineralization paragenetic sequence of Nochoon zone is given in Figure 9.

\subsection{Chemistry of Minerals}

\subsubsection{Chemistry of Pyroxene Minerals}

Clinopyroxene mineral is one of the paramount minerals in determining position of formation and geodynamic environment in igneous rocks, especially types of volcanic rocks. Approximation of temperature and pressure of volcanic rocks is also one of other cases that indicate importance of pyroxene minerals. In addition, composition of clinopyroxene minerals is a function of chemical compound and ambience to form builder of their magma and it can propose valuable

\begin{tabular}{|c|c|}
\hline Ore & Primary mineralization phases \\
\hline Magnetite & \\
\hline Pyrite & \\
\hline Chalcopyrite & \\
\hline Hematite & \\
\hline
\end{tabular}

Figure 9. Mineralization paragenetic sequence in Nochoon zone. 
information about tectonic environment in formation of rocks to us [1].

Based on results of microprobe analysis, all of analyzed pyroxene minerals are located within calcic limit in diagram of Q-J classification. Similarly, according to triangular terminological chart for pyroxenes, the pyroxene mineral is composed of diopside and augite types in these rocks (Figure 10). Generally, mineralography composition of this mineral is almost fixed in regional rocks and it varies approximately from $\mathrm{Wo}_{27.65} \mathrm{En}_{40.16} \mathrm{Fs}_{8.82}$ to $\mathrm{Wo}_{47.27} \mathrm{En}_{47.01} \mathrm{Fs}_{29.04}$. According to diagram [1] (Figure 11), most of samples have move away from territory of
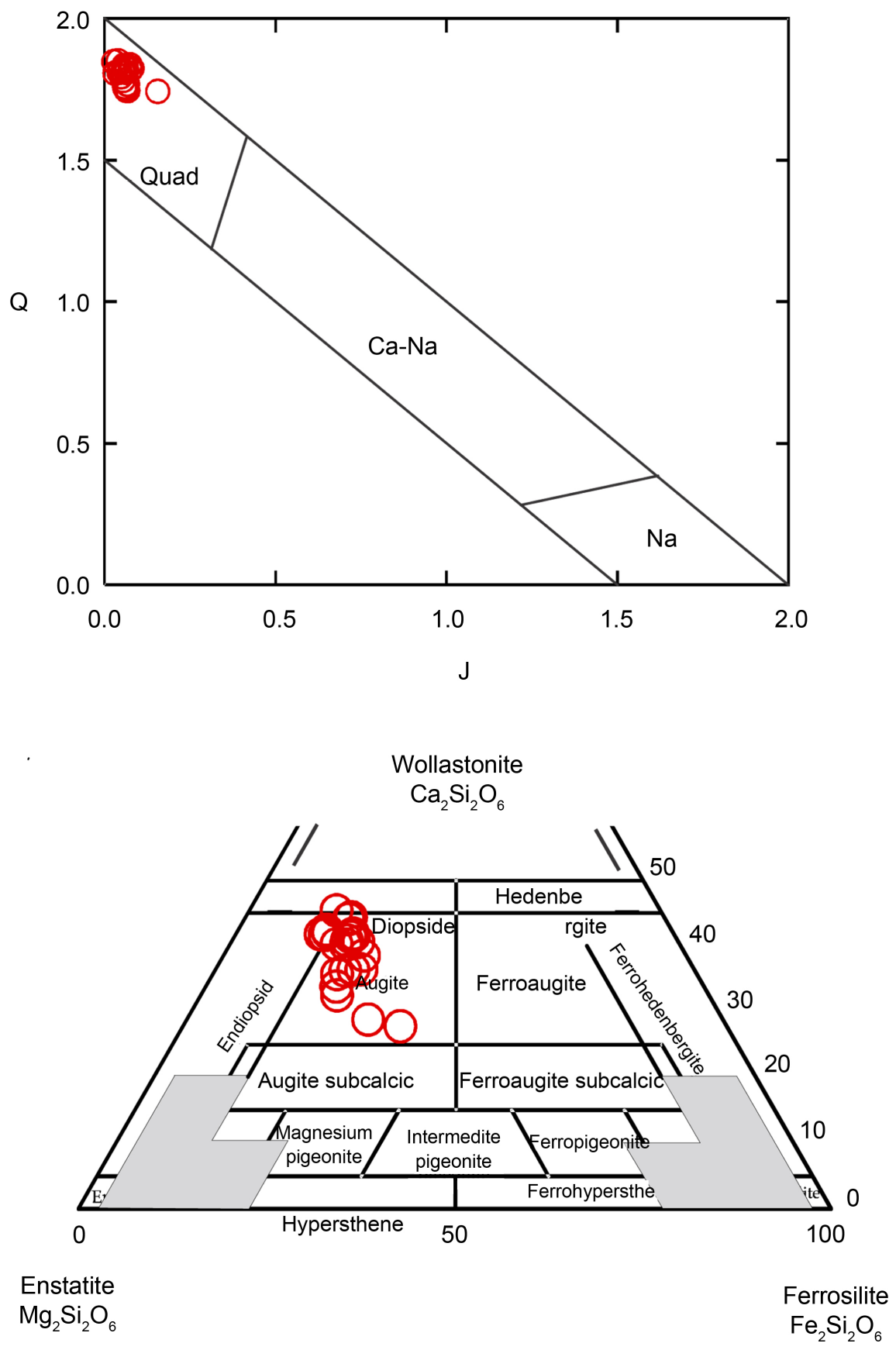

Figure 10. Diagram of taxonomy and terminology of the existing pyroxene minerals in volcanic rocks at Sarcheshmeh zone [2]. 
alkaline rocks due to shortage of $\mathrm{TiO}_{2}$ and they have been located within range of calc-alkaline rocks. Likewise, based on triangular diagram of $\mathrm{TiO}_{2}-\mathrm{SiO}_{2} / 100$ $\mathrm{Na}_{2} \mathrm{O}$, the studied clinopyroxene minerals show property of magmatic arcs in terms of tectonomagmatic environment (Figure 12). The low quantity of $\mathrm{TiO}_{2}$ in structural formula of the studied pyroxenes on the one hand and high rate of $\mathrm{SiO}_{2}$ on the other hand may indicate property of the existing pyroxenes in igneous rocks in volcanic arcs [3]. Microprobe analytical results for pyroxene are listed in Table 1.

\subsubsection{Chemistry of Amphibole}

All existing amphiboles in regional rocks belong to group of calcic amphiboles. Similarly, based on $\mathrm{Mg} /(\mathrm{Fe}+\mathrm{Mg})$ versus Si diagram, most of amphiboles in this

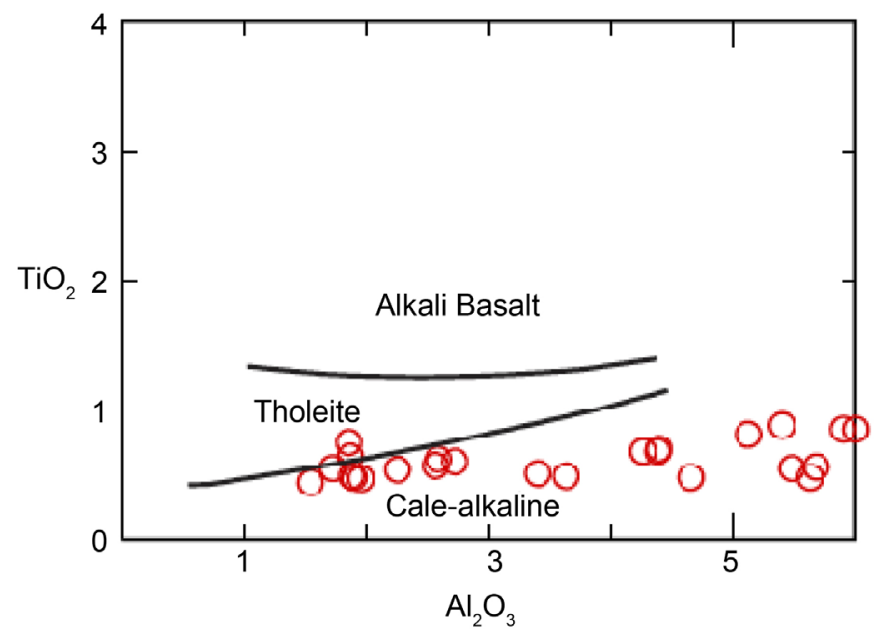

Figure 11. Determination of magmatic series in the studied samples using chemical composition of pyroxene in the variance diagram of $\mathrm{Al}_{2} \mathrm{O}_{3}-\mathrm{SiO}_{2}$ from [4].

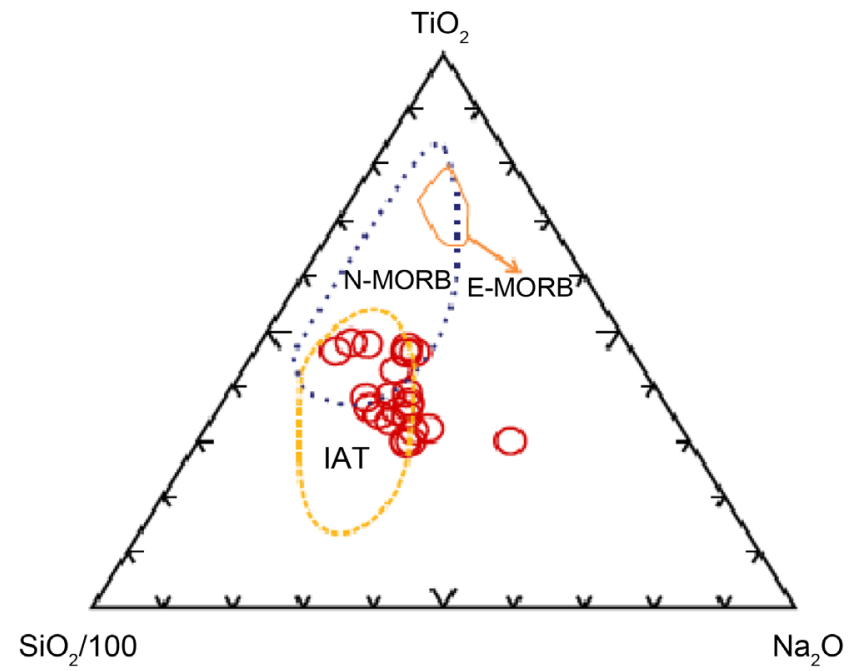

Figure 12. Determination of tectonic position of the studied samples using chemical composition of pyroxene in trivariate diagram of $\mathrm{Na}_{2} \mathrm{O}_{2}-\mathrm{SiO}-\mathrm{TiO}_{2}$ from [5]. 
Table 1. The results microprobe analysis on pyroxene at Sarcheshmeh zone.

\begin{tabular}{cccccccccc}
\hline Sample & $\mathrm{HS} 1$ & $\mathrm{HS} 2$ & $\mathrm{HS} 3$ & $\mathrm{HS} 4$ & $\mathrm{HS} 5$ & $\mathrm{HS6}$ & $\mathrm{HS7}$ & $\mathrm{HS} 8$ & $\mathrm{HS} 9$ \\
\hline $\mathrm{SiO}_{2}$ & 49.61 & 49.96 & 50.77 & 49.72 & 51.66 & 51 & 49.41 & 50.05 & 49.24 \\
$\mathrm{TiO}_{2}$ & 0.56 & 0.48 & 0.48 & 0.55 & 0.64 & 0.49 & 0.85 & 0.88 & 0.81 \\
$\mathrm{Al}_{2} \mathrm{O}_{3}$ & 5.68 & 5.63 & 4.65 & 5.48 & 1.86 & 3.63 & 5.9 & 5.4 & 5.12 \\
$\mathrm{MnO}$ & 0.13 & 0.11 & 0.15 & 0.13 & 0.28 & 0.2 & 0.23 & 0.15 & 0.18 \\
$\mathrm{MgO}$ & 15.17 & 15.25 & 15.65 & 15.45 & 15.68 & 15.34 & 13.84 & 14.11 & 14.07 \\
$\mathrm{CaO}$ & 22.75 & 23.09 & 22.74 & 22.67 & 20.34 & 22.29 & 22.23 & 22.35 & 22.76 \\
$\mathrm{Na}_{2} \mathrm{O}$ & 0.42 & 0.45 & 0.33 & 0.47 & 0.43 & 0.3 & 0.4 & 0.46 & 0.4 \\
$\mathrm{Cr}_{2} \mathrm{O}_{3}$ & 0.12 & 0.14 & 0.32 & 0.2 & 0.05 & 0 & 0 & 0 & 0 \\
$\mathrm{FeO}$ & 6.04 & 5.82 & 5.52 & 5.89 & 9.47 & 7.45 & 8.25 & 8.02 & 8.22 \\
\hline $\mathrm{Sample}$ & $\mathrm{HS} 10$ & $\mathrm{HS} 11$ & $\mathrm{HS} 12$ & $\mathrm{HS} 13$ & $\mathrm{HS} 14$ & $\mathrm{HS} 15$ & $\mathrm{HS} 16$ & $\mathrm{HS} 17$ & $\mathrm{HS} 18$ \\
\hline $\mathrm{SiO}_{2}$ & 49.28 & 51.34 & 52.55 & 51.52 & 52.23 & 51.99 & 52.05 & 51.57 & 51.62 \\
$\mathrm{TiO}_{2}$ & 0.85 & 0.7 & 0.47 & 0.6 & 0.55 & 0.48 & 0.49 & 0.44 & 0.54 \\
$\mathrm{Al}_{2} \mathrm{O}_{3}$ & 6 & 1.85 & 1.95 & 2.72 & 1.72 & 1.89 & 1.87 & 1.54 & 2.25 \\
$\mathrm{MnO}$ & 0.2 & 0.41 & 0.34 & 0.25 & 0.28 & 0.61 & 0.62 & 0.63 & 0.54 \\
$\mathrm{MgO}$ & 14.09 & 15.89 & 16.35 & 15.94 & 16.74 & 14.16 & 14.81 & 15.44 & 14.96 \\
$\mathrm{CaO}$ & 22.22 & 16.6 & 18.93 & 19.79 & 18.47 & 21.17 & 20.33 & 20.66 & 19.87 \\
$\mathrm{Na}_{2} \mathrm{O}$ & 0.44 & 0.26 & 0.51 & 0.44 & 0.55 & 0.52 & 0.38 & 0.43 & 0.4 \\
$\mathrm{Cr}_{2} \mathrm{O}_{3}$ & 0 & -0.01 & 0.13 & 0.33 & 0.05 & 0.02 & 0 & 0 & 0 \\
$\mathrm{FeO}$ & 8.05 & 13.78 & 9.38 & 8.81 & 9.98 & 10.2 & 10.75 & 10.25 & 10.64 \\
\hline
\end{tabular}

zone apparently seem to be of magnesiohostingsite type. Nonetheless, some of samples indicate magnesio-hornblende compound as well. Similarly, secondary amphiboles, which resulting from conversion of pyroxene mineral, show actinolithic composition (Figure 13). $\mathrm{FeO}, \mathrm{Al}_{2} \mathrm{O}_{3}$ content in this mineral includes wide changes and it varies $3.4 \%$ to $14 \%$ and $11.5 \%$ to $19 \%$ respectively (Table 2 ). Likewise, quantities of calcium and magnesium vary from $11.3 \%$ to $13 \%$ and $10.8 \%$ to $15.2 \%$ in them. In some samples in which amphibole mineral has been analyzed by microprobe from center of crystal to the margin, quantities of above acids have not shown noticeable changes that signify lack of zoning in this mineral.

\subsubsection{Chemistry of Plagioclase}

Composition of this mineral is very sensitive to temperature, pressure, and the existing water content in molten material [6] [7]. Plagioclase is present as one of the major minerals in composition of volcanic rocks in Sarcheshmeh zone. Surveying and study of microprobe analysis on plagioclase mineral in regional rocks shows that some of plagioclase minerals indicate wet calcic compounds so that the quantities of calcium is more increased from margin to margin in these minerals (Table 3). We utilized triangular diagram of Or-Ab-An to determine composition of plagioclase minerals in regional rocks (Figure 14). Based on these diagrams, existing plagioclases in regional rocks show wide composition from albite to bitonit. Plagioclases with bitonit composition indicate compounds 
Table 2. The results of microprobe analysis on amphiboles at Sarcheshmeh zone.

\begin{tabular}{|c|c|c|c|c|c|c|c|c|c|}
\hline Sample & HHK1 & HHK2 & HHK3 & HHK4 & HHK5 & HHK6 & HHK7 & HHK8 & HHK9 \\
\hline $\mathrm{SiO}_{2}$ & 48.04 & 49.4 & 49.44 & 48.58 & 52.99 & 42.4 & 41.44 & 41.8 & 41.94 \\
\hline $\mathrm{TiO}_{2}$ & 0.11 & 0.22 & 0.24 & 0.39 & 0.01 & 1.86 & 1.67 & 2.39 & 2.36 \\
\hline $\mathrm{Al}_{2} \mathrm{O}_{3}$ & 6.97 & 6.43 & 5.64 & 6.97 & 3.44 & 13.1 & 12.86 & 13.9 & 13.74 \\
\hline $\mathrm{MnO}$ & 0.38 & 0.38 & 0.71 & 0.51 & 0.37 & 0.42 & 0.41 & 0.17 & 0.13 \\
\hline $\mathrm{MgO}$ & 11.15 & 11.91 & 10.84 & 11.37 & 14.8 & 12.66 & 12.37 & 14.59 & 14.62 \\
\hline $\mathrm{CaO}$ & 12.44 & 12.72 & 12.41 & 12.64 & 12.98 & 11.83 & 12.04 & 12.09 & 12.14 \\
\hline $\mathrm{Na}_{2} \mathrm{O}$ & 0.47 & 0.48 & 0.32 & 0.5 & 0.22 & 2.44 & 2.46 & 2.54 & 2.54 \\
\hline $\mathrm{K}_{2} \mathrm{O}$ & 0.22 & 0.2 & 0.24 & 0.32 & 0.07 & 0.91 & 0.92 & 0.89 & 0.87 \\
\hline $\mathrm{FeO}$ & 18.17 & 17.68 & 19.02 & 17.65 & 13.76 & 15.15 & 15.32 & 11.95 & 11.54 \\
\hline $\mathrm{Si}$ & 7.06 & 7.14 & 7.23 & 7.08 & 7.58 & 6.05 & 6.02 & 5.92 & 5.96 \\
\hline $\mathrm{Al}$ iv & 0.94 & 0.86 & 0.77 & 0.92 & 0.42 & 1.95 & 1.98 & 2.08 & 2.04 \\
\hline $\mathrm{Al} \mathrm{vi}$ & 0.26 & 0.23 & 0.20 & 0.27 & 0.15 & 0.25 & 0.22 & 0.23 & 0.26 \\
\hline $\mathrm{Fe}^{3+}$ & 0.56 & 0.48 & 0.50 & 0.42 & 0.22 & 0.85 & 0.77 & 0.82 & 0.72 \\
\hline $\mathrm{Fe}^{2+}$ & 1.67 & 1.66 & 1.82 & 1.73 & 1.43 & 0.96 & 1.09 & 0.59 & 0.66 \\
\hline $\mathrm{Mg}$ & 2.44 & 2.56 & 2.36 & 2.47 & 3.15 & 2.69 & 2.68 & 3.08 & 3.10 \\
\hline $\mathrm{Ca}$ & 1.96 & 1.97 & 1.94 & 1.97 & 1.99 & 1.81 & 1.87 & 1.83 & 1.85 \\
\hline $\mathrm{Na}$ & 0.13 & 0.13 & 0.09 & 0.14 & 0.06 & 0.67 & 0.69 & 0.70 & 0.70 \\
\hline $\mathrm{K}$ & 0.04 & 0.04 & 0.04 & 0.06 & 0.01 & 0.17 & 0.17 & 0.16 & 0.16 \\
\hline Sample & HHK10 & HHK11 & HHK12 & HHK13 & HHK14 & HHK15 & HHK16 & HHK17 & HHK18 \\
\hline $\mathrm{SiO}_{2}$ & 42.19 & 42.65 & 41.8 & 41.77 & 42.14 & 42.5 & 41.05 & 41.93 & 42.16 \\
\hline $\mathrm{TiO}_{2}$ & 2.37 & 2.1 & 2.08 & 2.51 & 2.38 & 2.37 & 2.4 & 2.26 & 2.15 \\
\hline $\mathrm{Al}_{2} \mathrm{O}_{3}$ & 13.48 & 12.96 & 13.17 & 13.95 & 13.58 & 13.29 & 13.27 & 13.44 & 13.95 \\
\hline $\mathrm{MnO}$ & 0.16 & 0.22 & 0.27 & 0.16 & 0.15 & 0.21 & 0.17 & 0.2 & 0.19 \\
\hline $\mathrm{MgO}$ & 14.75 & 13.91 & 13.53 & 14.16 & 14.26 & 14.27 & 13.9 & 14.26 & 15.23 \\
\hline $\mathrm{CaO}$ & 12.21 & 12.15 & 12.08 & 12.02 & 12.1 & 12.17 & 12.03 & 12.09 & 11.9 \\
\hline $\mathrm{Na}_{2} \mathrm{O}$ & 2.39 & 2.54 & 2.5 & 2.49 & 2.47 & 2.46 & 2.28 & 2.44 & 2.64 \\
\hline $\mathrm{K}_{2} \mathrm{O}$ & 0.84 & 0.99 & 1.03 & 0.97 & 0.92 & 0.92 & 0.94 & 0.96 & 0.96 \\
\hline $\mathrm{FeO}$ & 11.55 & 12.83 & 13.49 & 11.89 & 11.9 & 12.01 & 12.28 & 12.19 & 12.17 \\
\hline $\mathrm{Si}$ & 5.98 & 6.08 & 6 & 5.95 & 6 & 6.04 & 5.95 & 5.98 & 5.88 \\
\hline $\mathrm{Al}$ iv & 2.02 & 1.92 & 2 & 2.05 & 2 & 1.96 & 2.05 & 2.02 & 2.12 \\
\hline $\mathrm{Al}$ vi & 0.24 & 0.26 & 0.23 & 0.29 & 0.28 & 0.27 & 0.22 & 0.24 & 0.17 \\
\hline $\mathrm{Fe}^{3+}$ & 0.75 & 0.61 & 0.72 & 0.69 & 0.66 & 0.63 & 0.75 & 0.74 & 1.06 \\
\hline $\mathrm{Fe}^{2+}$ & 0.62 & 0.92 & 0.90 & 0.72 & 0.75 & 0.80 & 0.74 & 0.72 & 0.35 \\
\hline $\mathrm{Mg}$ & 3.12 & 2.96 & 2.90 & 3.01 & 3.03 & 3.02 & 3.01 & 3.03 & 3.16 \\
\hline $\mathrm{Ca}$ & 1.86 & 1.86 & 1.86 & 1.83 & 1.85 & 1.85 & 1.87 & 1.85 & 1.78 \\
\hline $\mathrm{Na}$ & 0.66 & 0.70 & 0.70 & 0.69 & 0.68 & 0.68 & 0.64 & 0.68 & 0.71 \\
\hline $\mathrm{K}$ & 0.15 & 0.18 & 0.19 & 0.18 & 0.17 & 0.17 & 0.17 & 0.17 & 0.17 \\
\hline
\end{tabular}




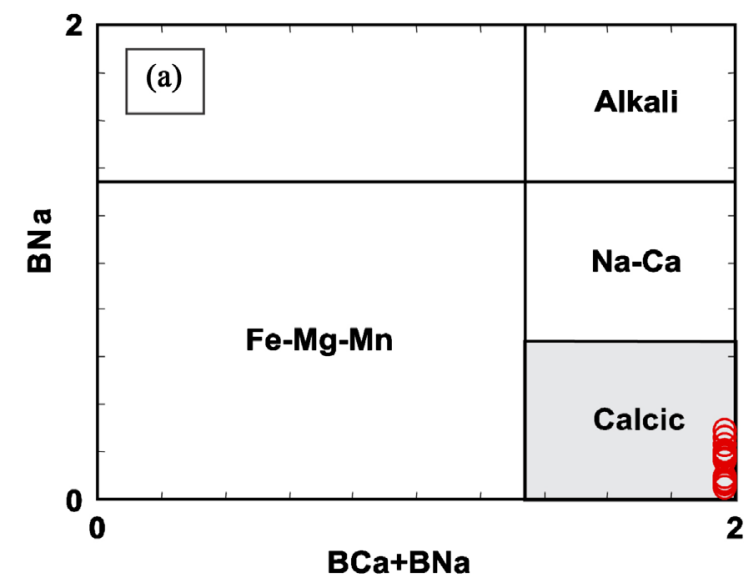

Calcic Amphiboles $(\mathrm{Ca}+\mathrm{Na})_{B} \geq 1.00$ and $1.50>(\mathrm{Na})_{B}>0.50$ $(\mathrm{Ca})_{A}<0.50 ;(\mathrm{Na}+\mathrm{K})_{A}<0.50$

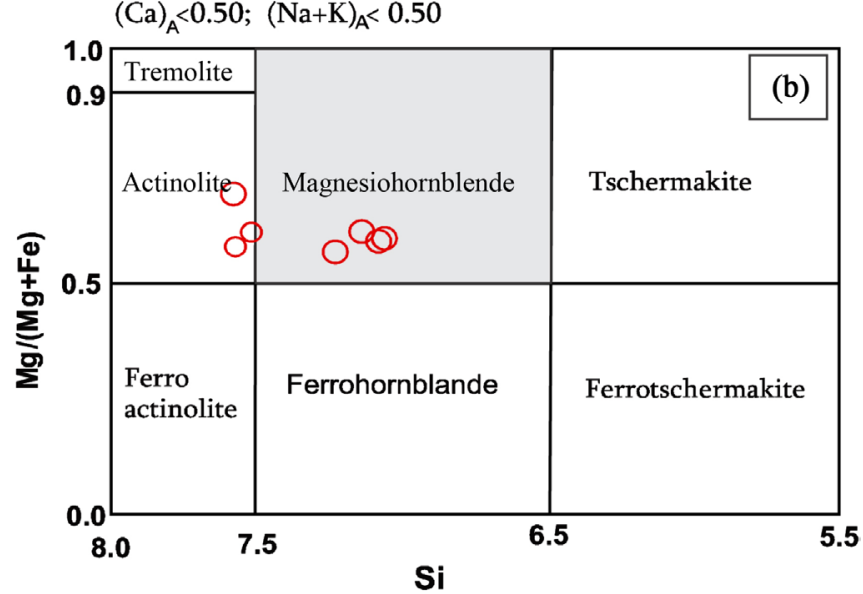

Calcic Amphiboles $(\mathrm{Ca}+\mathrm{Na})_{B} 1.00$ and $1.50>(\mathrm{Na})_{B}>0.50$ $(\mathrm{Ca})_{B} \geq 1.50 ;(\mathrm{Na}+\mathrm{K})_{A} \geq 0.50 ; \mathrm{Ti}<0.50$

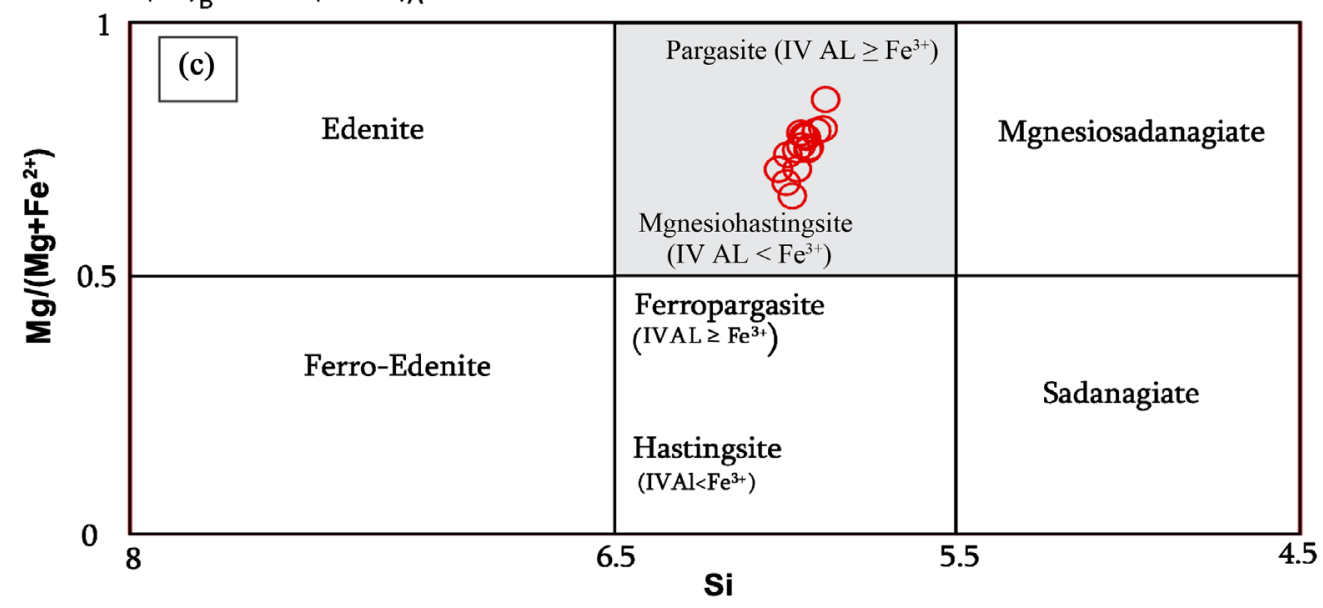

Figure 13. The composition of the existing amphiboles in rock of the zone in diagram of classification of amphiboles [8].

belonging to wet calcic crystals. Likewise, results of conducted analyses on a pyroclastic sample indicate that plagioclase minerals in this sample possess calcic property and show composition of labradorite to bitonit.

\subsubsection{Chemistry of Chlorite}

Minerals in chlorite group include wide range of chemical compound that reflects their crystallization under physicochemical conditions. The most common chlorine compounds with formula $\left(\mathrm{Mg}_{4} \mathrm{AL}_{2}\right)\left(\mathrm{Si}_{2} \mathrm{Al}_{2}\right) \mathrm{O}_{10}(\mathrm{OH})_{8}$ is placed among antigorite $\mathrm{Mg}_{6} \mathrm{Si}_{4} \mathrm{O}_{10}(\mathrm{OH})_{8}$ and amosite in which there is succession of $\mathrm{Fe}^{2+}$ instead of $\mathrm{Mg}^{2+}$. The solid solution (cationic succession) model in chlorite crystal grid has been more successfully in determination of crystallization temperature of this mineral in various geologic environments such as mineral deposits, hydrothermal alterations, low-degree alteration, and diagenesis by some researchers. Analysis results (Table 4) indicate that the existing chlorite contents in volcanic rocks in Sarcheshmeh zone show pycnochlorite and clinochlore compounds (Figure 15). 


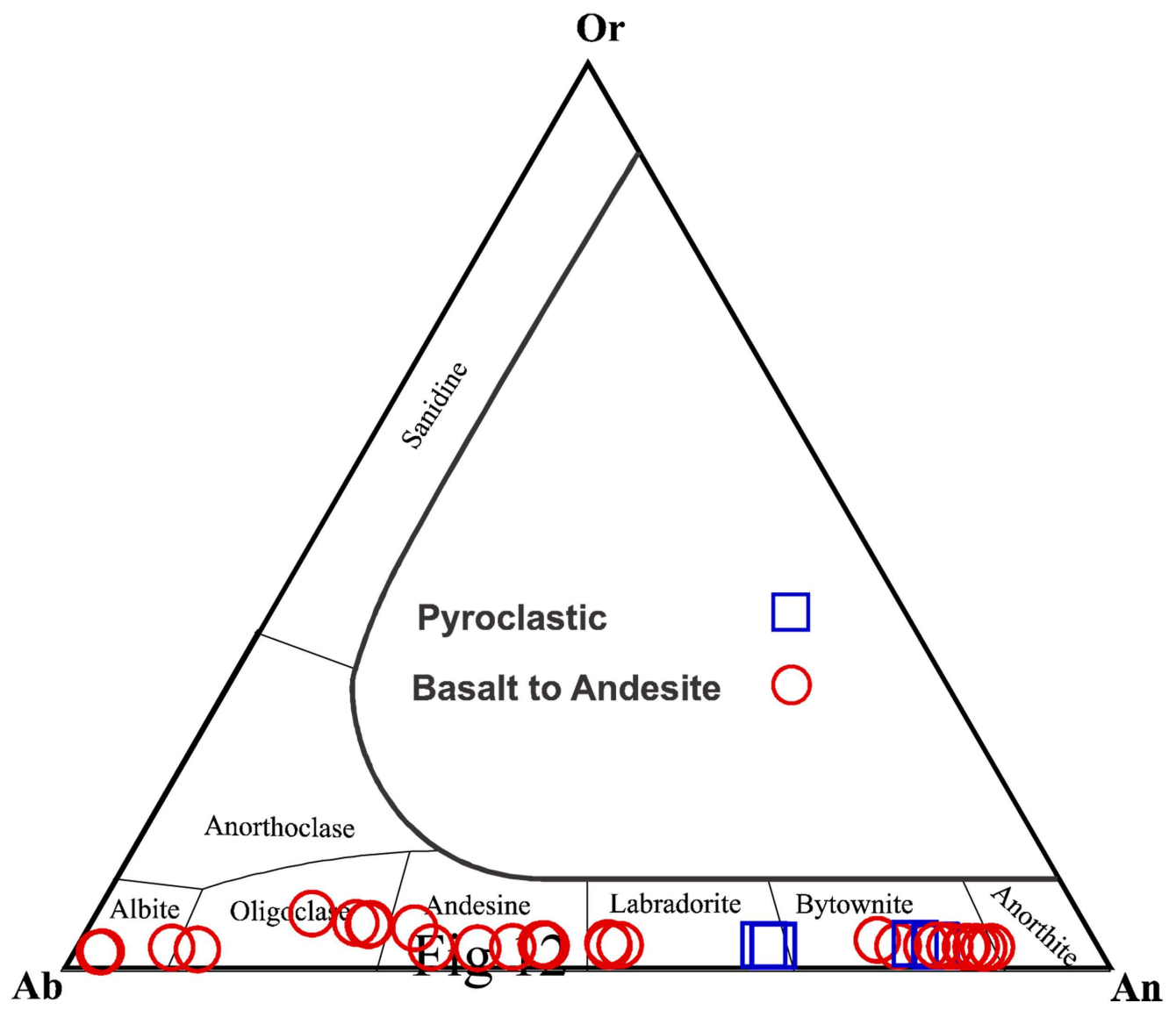

Figure 14. Diagram of determination of plagioclase composition in rocks of the zone: Plagioclase composition in rocks of this zone covers wide range from albite to bitonit.

\section{Conclusion}

The studied rocks in Sarcheshmeh zone include extrusive and intrusive igneous rocks. The group of extrusive igneous rocks comprises of 1) andesite and 2) rhyodacite. Intrusive igneous group includes 1) monzogranite, 2) porphyritic diorite, and 3) porphyritic granodiorite and group of extrusive igneous rocks are placed in Nochoon mine including 1) andesite and 2) dacite. The major ores in studied sections of Sarcheshmeh zone consist of pyrite, chalcopyrite, and magnetite. The subsidiary minerals also include chalcocite, covellite, bornite, and hematite. We may find it by comparing mineralization of magnetite and hematite in Nochoon with Sarcheshmeh zone that magnetite mineral is less spread in background rock in Nochoon. Alternately, rate of conversion of magnetite to hematite is higher in Nochoon than in Sarcheshmeh zone and magnetite is more under influence of hydrothermal solutions in Nochoon. It is characterized by comparison of pyrite and chalcopyrite mineralization in Nochoon versus Sarcheshmeh that mineralization is different in the two ores with each other in terms of paragenetic sequence and various generations. Based on microprobe analytical results, composition of pyroxene mineral in these rocks is diopside and augite type and regional amphiboles indicate a composition of magnesiohostingsite and existing plagioclases in regional rock and the composition of 
Table 3. The results of microprobe analysis on plagioclase in Sarcheshmeh zone.

\begin{tabular}{|c|c|c|c|c|c|c|c|c|c|}
\hline Sample & $\mathrm{HH} 1$ & $\mathrm{HH} 2$ & HH3 & $\mathrm{HH} 4$ & HH5 & HH6 & $\mathrm{HH7}$ & HH8 & HH9 \\
\hline $\mathrm{SiO}_{2}$ & 46.87 & 47.75 & 55.19 & 44.77 & 44.71 & 50.13 & 65.5 & 66.12 & 68.1 \\
\hline $\mathrm{TiO}_{2}$ & 0.04 & 0.03 & 0.06 & 0.01 & 0.02 & 0.05 & 0 & 0 & 0 \\
\hline $\mathrm{Al}_{2} \mathrm{O}_{3}$ & 32.82 & 32.62 & 27.85 & 33.57 & 33.58 & 29.31 & 21.21 & 20.36 & 19.84 \\
\hline $\mathrm{MnO}$ & 0.01 & 0.01 & 0 & 0.01 & 0.01 & 0.01 & 0 & 0 & 0 \\
\hline $\mathrm{MgO}$ & 0.1 & 0.13 & 0.05 & 0.07 & 0.07 & 0.16 & 0.01 & 0 & 0.01 \\
\hline $\mathrm{CaO}$ & 17.33 & 16.91 & 11.13 & 18.82 & 18.64 & 14.92 & 2.76 & 2.2 & 0.21 \\
\hline $\mathrm{Na}_{2} \mathrm{O}$ & 1.97 & 2.31 & 5.65 & 1.17 & 1.26 & 2.28 & 10.93 & 11.36 & 12.63 \\
\hline $\mathrm{K}_{2} \mathrm{O}$ & 0.05 & 0.05 & 0.23 & 0.03 & 0.01 & 0.15 & 0.1 & 0.14 & 0.08 \\
\hline $\mathrm{FeO}$ & 0.6 & 0.63 & 0.7 & 0.57 & 0.65 & 0.94 & 0.18 & 0.1 & 0.02 \\
\hline An & 82.7 & 80 & 51.5 & 89.7 & 89.1 & 77.6 & 12.2 & 9.6 & 0.9 \\
\hline $\mathrm{Ab}$ & 17 & 19.8 & 47.3 & 10.1 & 10.9 & 21.5 & 87.3 & 89.7 & 98.7 \\
\hline Or & 0.3 & 0.3 & 1.3 & 0.2 & 0.1 & 0.9 & 0.5 & 0.7 & 0.4 \\
\hline Sample & HH10 & HH11 & HH12 & HH13 & HH14 & HH15 & HH16 & HH17 & HH18 \\
\hline $\mathrm{SiO}_{2}$ & 67.45 & 67.99 & 62.45 & 60.87 & 60.87 & 59.7 & 60.93 & 60.49 & 57.11 \\
\hline $\mathrm{TiO}_{2}$ & 0 & 0 & 0.02 & 0.01 & 0 & 0 & 0.03 & 0.02 & 0.09 \\
\hline $\mathrm{Al}_{2} \mathrm{O}_{3}$ & 20.08 & 19.78 & 23 & 24.13 & 23.62 & 25.1 & 24.04 & 24.22 & 26.33 \\
\hline $\mathrm{MnO}$ & 0.02 & 0.01 & 0 & 0 & 0.01 & 0 & 0.01 & 0 & 0 \\
\hline $\mathrm{MgO}$ & 0 & 0 & 0 & 0 & 0 & 0 & 0 & 0 & 0.08 \\
\hline $\mathrm{CaO}$ & 0.16 & 0.22 & 4.67 & 5.86 & 5.67 & 7 & 5.92 & 5.91 & 9.76 \\
\hline $\mathrm{Na}_{2} \mathrm{O}$ & 13.02 & 12.43 & 9.11 & 8.22 & 8.56 & 7.9 & 8.37 & 8.36 & 6.43 \\
\hline $\mathrm{K}_{2} \mathrm{O}$ & 0.09 & 0.11 & 1 & 0.76 & 0.8 & 0.61 & 0.76 & 0.75 & 0.28 \\
\hline $\mathrm{FeO}$ & 0.03 & 0.07 & 0.15 & 0.15 & 0.18 & 0.13 & 0.16 & 0.16 & 0.8 \\
\hline An & 0.7 & 1 & 20.9 & 27.1 & 25.6 & 31.8 & 26.9 & 26.9 & 44.9 \\
\hline $\mathrm{Ab}$ & 98.9 & 98.5 & 73.8 & 68.7 & 70.1 & 64.9 & 68.9 & 69 & 53.5 \\
\hline Or & 0.4 & 0.6 & 5.3 & 4.2 & 4.3 & 3.3 & 4.1 & 4.1 & 1.5 \\
\hline Sample & HH19 & HH20 & HH21 & HH22 & $\mathrm{HH} 23$ & $\mathrm{HH} 24$ & HH25 & HH26 & $\mathrm{HH} 27$ \\
\hline $\mathrm{SiO}_{2}$ & 54.78 & 56.72 & 59.14 & 57.41 & 54.77 & 56.06 & 57.7 & 50.33 & 46.33 \\
\hline $\mathrm{TiO}_{2}$ & 0.09 & 0.08 & 0.02 & 0.05 & 0.05 & 0.04 & 0.05 & 0.05 & 0.02 \\
\hline $\mathrm{Al}_{2} \mathrm{O}_{3}$ & 26.96 & 26.49 & 21.05 & 26.35 & 27.93 & 26.94 & 25.76 & 29.13 & 32.13 \\
\hline $\mathrm{MnO}$ & 0 & 0.01 & 0.01 & 0 & 0.01 & 0 & 0.01 & 0.01 & 0.02 \\
\hline $\mathrm{MgO}$ & 0.15 & 0.08 & 0 & 0 & 0 & 0.03 & 0 & 0.06 & 0.05 \\
\hline $\mathrm{CaO}$ & 11.24 & 9.96 & 8.65 & 9.1 & 11.14 & 9.76 & 8.45 & 14.06 & 17.24 \\
\hline $\mathrm{Na}_{2} \mathrm{O}$ & 5.44 & 6.44 & 8.93 & 6.71 & 5.63 & 6.36 & 7.17 & 3.78 & 1.85 \\
\hline $\mathrm{K}_{2} \mathrm{O}$ & 0.19 & 0.25 & 0.25 & 0.22 & 0.17 & 0.28 & 0.2 & 0.14 & 0.05 \\
\hline $\mathrm{FeO}$ & 0.84 & 0.7 & -0.11 & 0.36 & 0.43 & 0.4 & 0.31 & 1 & 0.72 \\
\hline An & 52.7 & 45.5 & 34.5 & 42.3 & 51.7 & 45.2 & 39 & 66.7 & 83.5 \\
\hline $\mathrm{Ab}$ & 46.2 & 53.2 & 64.4 & 56.5 & 47.3 & 53.3 & 59.9 & 32.5 & 16.2 \\
\hline Or & 1.1 & 1.4 & 1.2 & 1.2 & 0.9 & 1.5 & 1.1 & 0.8 & 0.3 \\
\hline Sample & HH28 & HH29 & НH30 & HH31 & HH32 & НH33 & HH34 & HH35 & \\
\hline $\mathrm{SiO}_{2}$ & 46.9 & 45.85 & 50.3 & 46.02 & 45.01 & 45.36 & 45.77 & 45.81 & \\
\hline $\mathrm{TiO}_{2}$ & 0.02 & 0.02 & 0.04 & 0.02 & 0.03 & 0 & 0.02 & 0.05 & \\
\hline $\mathrm{Al}_{2} \mathrm{O}_{3}$ & 31.65 & 31.79 & 29.25 & 32.33 & 32.74 & 33.09 & 32.65 & 32.76 & \\
\hline
\end{tabular}




\section{Continued}

\begin{tabular}{ccccccccc}
\hline $\mathrm{MnO}$ & 0 & 0 & 0.01 & 0.02 & 0.01 & 0.01 & 0 & 0.03 \\
$\mathrm{MgO}$ & 0.1 & 0.05 & 0.09 & 0.05 & 0.04 & 0.02 & 0.03 & 0.06 \\
$\mathrm{CaO}$ & 16.93 & 17.34 & 14.15 & 17.48 & 18.24 & 18.18 & 17.63 & 17.5 \\
$\mathrm{Na}_{2} \mathrm{O}$ & 2.07 & 1.84 & 3.65 & 1.84 & 1.55 & 1.41 & 1.7 & 1.47 \\
$\mathrm{~K}_{2} \mathrm{O}$ & 0.09 & 0.04 & 0.12 & 0.06 & 0.03 & 0.03 & 0.04 & 0.03 \\
$\mathrm{FeO}$ & 0.68 & 0.64 & 0.94 & 0.62 & 0.63 & 0.59 & 0.67 & 0.61 \\
$\mathrm{An}$ & 81.5 & 83.7 & 67.7 & 83.7 & 86.5 & 87.5 & 84.9 & 86.7 \\
$\mathrm{Ab}$ & 18 & 16.1 & 31.6 & 15.9 & 13.3 & 12.3 & 14.8 & 13.2 \\
$\mathrm{Or}$ & 0.5 & 0.2 & 0.7 & 0.3 & 0.2 & 0.2 & 0.2 & 0.2 \\
\hline
\end{tabular}

Table 4. The results of microprobe analysis on chlorites in Sarcheshmeh zone.

\begin{tabular}{|c|c|c|c|c|c|c|c|c|c|}
\hline Sample & HB1 & HB2 & HB3 & HB4 & HB5 & HB6 & HB7 & HB8 & HB9 \\
\hline $\mathrm{SiO}_{2}$ & 29.4 & 31.1 & 29.11 & 30.02 & 30.92 & 30.99 & 28.22 & 28.99 & 30.28 \\
\hline $\mathrm{TiO}_{2}$ & 0.01 & 0 & 0.01 & 0.01 & 0 & 0.01 & 0.04 & 0.01 & 0.01 \\
\hline $\mathrm{Al}_{2} \mathrm{O}_{3}$ & 18.12 & 20.08 & 18.18 & 18.66 & 19.01 & 19.19 & 18.61 & 19.22 & 19.84 \\
\hline $\mathrm{MnO}$ & 0.49 & 0.5 & 0.48 & 0.43 & 0.5 & 0.47 & 0.44 & 0.38 & 0.39 \\
\hline $\mathrm{MgO}$ & 18.91 & 20.34 & 18.87 & 19.04 & 20.63 & 20.78 & 18.59 & 19.24 & 20.52 \\
\hline $\mathrm{CaO}$ & 0.1 & 0.09 & 0.15 & 0.05 & 0.06 & 0.09 & 0.08 & 0.1 & 0.14 \\
\hline $\mathrm{Na}_{2} \mathrm{O}$ & 0.15 & 0.02 & 0.03 & 0.04 & 0.36 & 0.14 & 0.08 & 0.16 & 0.05 \\
\hline $\mathrm{K}_{2} \mathrm{O}$ & 0.03 & 0.02 & 0.01 & 0.04 & 0.02 & 0.02 & 0 & 0.01 & 0.05 \\
\hline $\mathrm{FeO}$ & 22.72 & 22.43 & 22.5 & 22.89 & 21.7 & 22.08 & 21.52 & 21.75 & 21.46 \\
\hline Sample & HB10 & HB11 & $\mathrm{HB} 12$ & HB13 & HB14 & HB15 & HB16 & & \\
\hline $\mathrm{SiO}_{2}$ & 29.49 & 29.01 & 29.26 & 29.4 & 33.16 & 32.91 & 32.62 & & \\
\hline $\mathrm{TiO}_{2}$ & 0.01 & 0 & 0 & 0.02 & 0 & 0.01 & 0 & & \\
\hline $\mathrm{Al}_{2} \mathrm{O}_{3}$ & 17.89 & 16.96 & 17.55 & 16.7 & 16.36 & 17.44 & 18.95 & & \\
\hline $\mathrm{MnO}$ & 0.3 & 0.28 & 0.27 & 0.3 & 0.32 & 0.33 & 0.36 & & \\
\hline $\mathrm{MgO}$ & 19.12 & 18.74 & 18.71 & 18.2 & 25.11 & 27.08 & 23.82 & & \\
\hline $\mathrm{CaO}$ & 0.16 & 0.23 & 0.18 & 0.14 & 0.17 & 0.1 & 0.15 & & \\
\hline $\mathrm{Na}_{2} \mathrm{O}$ & 0.28 & 0.13 & 0.07 & 0.02 & 0 & 0.08 & 0.08 & & \\
\hline $\mathrm{K}_{2} \mathrm{O}$ & 0.02 & 0 & 0.02 & 0.03 & 0.14 & 0.06 & 0.13 & & \\
\hline $\mathrm{FeO}$ & 21.98 & 22.32 & 22.16 & 22.52 & 12.43 & 11.95 & 12.73 & & \\
\hline
\end{tabular}

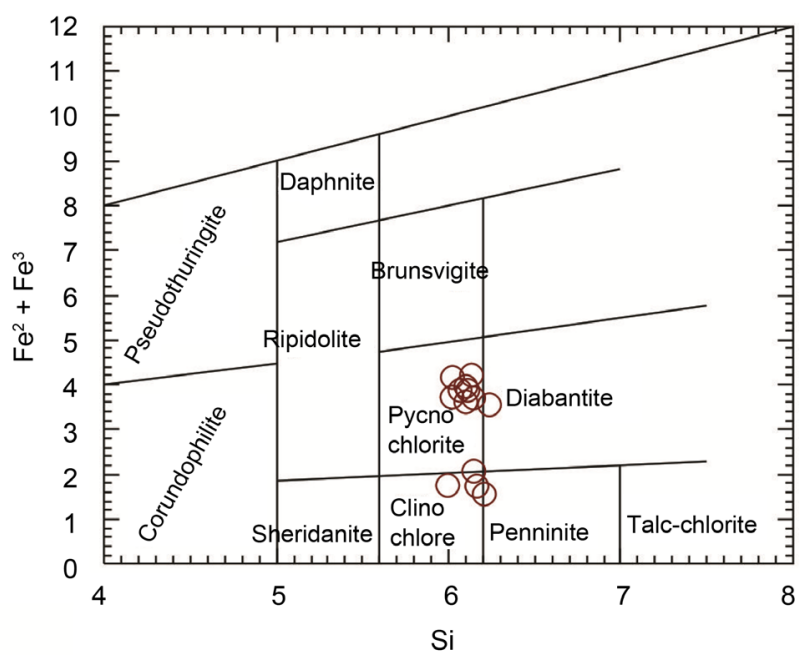

Figure 15. Diagram of determination of composition of chlorites in rocks of the zone. 
labradorite and bitonit.

\section{References}

[1] Le Bas, M.J., Le Maitre, R.W., Streckeisen, A. and Zanettin, B. (1986) A Chemical Classification of Volcanic Rocks Based on the Total Alkali-Silica Diagram. Journal of Petrology, 27, 745-750. https://doi.org/10.1093/petrology/27.3.745

[2] Le Maitre, R.W., Bateman, P., Dudek, A.J. and Keller, M.J. (1989) A Classification of Igneous Rocks and Glossary of Terms, Blackwell, Oxford, 193.

[3] Lu Muller, D. and Groves, D.I. (1997) Potassic Igneous Rocks and Associated Goldcopper Mineralization, Second Updated. Springer Vrelag, Berlin, 242 p.

[4] Irvine, T.N. and Baragar, W.R.A. (1971) A Guide to the Chemical Classification of the Common Volcanic Rocks. Canadian Journal of Earth Science, 8, 523-548. https://doi.org/10.1139/e71-055

[5] Berndt, J., Koepke, J. and Holtz, F. (2005) Influence of $\mathrm{H}_{2} \mathrm{O}$ and Oxygen Fugacity on Differentiation of MORB at $200 \mathrm{MPa}$. Journal of Petrology, 46, 135-167.

https://doi.org/10.1093/petrology/egh066

[6] Pechersky, D.M. and Genshaft, Y.S. (2001) Petromagnetism of the Continental Lithosphere and the Origin of Regional Magnetic Anomalies: A Review. Russian Journal of Earth Sciences, 3, 97-124. https://doi.org/10.2205/2001ES000059

[7] Pearce, J.A. and Cann, J.R. (1973) Tectonic Setting of Basic Volcanic Rocks Determined Using Trace Element Analyses. Earth and Planetary Science Letters, 19, 290300. https://doi.org/10.1016/0012-821X(73)90129-5

[8] Pearce, J.A. (1983) Role of Sub-Continental Lithosphere in Magma Genesis at Active Continental Margins. In: Hawkesworth, C.J. and Nurry, M.L., Eds., Continental Basalts and Mantle Xenoliths, Shiva, Nantwich, 230-249.

\section{Submit or recommend next manuscript to SCIRP and we will provide best service for you:}

Accepting pre-submission inquiries through Email, Facebook, LinkedIn, Twitter, etc. A wide selection of journals (inclusive of 9 subjects, more than 200 journals)

Providing 24-hour high-quality service

User-friendly online submission system

Fair and swift peer-review system

Efficient typesetting and proofreading procedure

Display of the result of downloads and visits, as well as the number of cited articles

Maximum dissemination of your research work

Submit your manuscript at: http://papersubmission.scirp.org/

Or contact ojg@scirp.org 